\title{
The distribution of copper, zinc and manganese in various regions of the brain and in other tissues of children with protein-calorie malnutrition
}

\author{
By B. H. LEHMANN, J. D. L. HANSEN AND P. J. WARREN* \\ Department of Paediatrics and Child Health, The University of Cape Town, \\ Observatory, Cape, Republic of South Africa
}

(Received 8 September 1970-Accepted 4 March 197I)

\begin{abstract}
1. The distribution of copper, zinc and manganese in seven regions of the brain, liver, heart, muscle from the abdominal wall, and skin of children was determined by means of atomic absorption spectrophotometry.

2. The results showed significantly lower levels of $\mathrm{Cu}, \mathrm{Zn}$ and $\mathrm{Mn}$ in livers of children with kwashiorkor compared with control subjects. The concentrations of these three elements were higher in livers of children with marasmus than in livers of children suffering from kwashiorkor and not significantly different from those of control subjects.

3. The $\mathrm{Cu}$ concentration in muscle obtained from the abdominal wall of subjects with kwashiorkor and the $\mathrm{Mn}$ concentration in heart muscle of all groups with protein-calorie malnutrition were significantly lower than the respective values for the control group.

4. There was no significant difference between $\mathrm{Cu}, \mathrm{Zn}$ or Mn concentration in brain tissues of control subjects and in those with protein-calorie malnutrition.
\end{abstract}

Severe protein-calorie malnutrition (PCM) is known to produce an imbalance of the major mineral elements of the body. Depletion of potassium and magnesium are often seen in acute cases of kwashiorkor. Recent findings (Hansen \& Lehmann, 1969) confirm the fact that zinc and copper concentrations in the serum of patients suffering from protein-calorie malnutrition can be very low.

Warren, Hansen \& Lehmann ( 1969 ) determined the concentrations of $\mathrm{Cu}, \mathrm{Zn}$ and manganese in the liver of children suffering from kwashiorkor and compared these findings with those obtained for marasmic children, and children who had died from other causes. This study showed that there was a significant decrease of the concentrations of $\mathrm{Zn}$ and $\mathrm{Cu}$ in the liver of kwashiorkor patients compared with controls.

As far as we are aware, no observations have been made of the effect of severe PCM on the concentrations of trace metals such as $\mathrm{Zn}, \mathrm{Cu}$ and $\mathrm{Mn}$ in the brain. It seemed to us desirable to investigate whether severe PCM in young children altered the concentration of any of these trace metals. This study might indicate whether reduction in the liver concentrations of $\mathrm{Cu}$ and $\mathrm{Zn}$ were reflected in the concentrations of these metals in the brain. In this communication the concentrations of $\mathrm{Cu}, \mathrm{Zn}$ and $\mathrm{Mn}$ in various regions of the brain, liver, muscle obtained from the wall of the abdomen, and skin of children who had died from kwashiorkor and marasmus are presented.

* Present address: Department of Biochemistry, The London Hospital Medical College, London, EI $2 A D$. 


\section{EXPERIMENTAL}

\section{Material}

Samples of brain, liver, heart, muscle obtained from the wall of the abdomen, and skin were obtained at autopsy from five children with kwashiorkor, three with marasmic kwashiorkor, and six with marasmus. Five children of the same age range that had died of diseases other than kwashiorkor or marasmus and showed no obvious signs of malnutrition were the only subjects available to serve as a control group (Table I). The criteria for diagnosis of kwashiorkor, marasmic kwashiorkor and marasmus were those outlined by Jelliffe (I966).

\section{Table I. Information about the children studied}

\begin{tabular}{|c|c|c|c|}
\hline Code & Age & Sex & Cause of death \\
\hline $\begin{array}{l}166 / 67 \\
170 / 67 \\
171 / 67 \\
236 / 67 \\
252 / 67\end{array}$ & $\begin{array}{l}\text { I year } 5 \text { months } \\
9 \text { months } \\
\text { I year } 6 \text { months } \\
\text { I year } 6 \text { months } \\
2 \text { years } 4 \text { months }\end{array}$ & $\begin{array}{l}q \\
a \\
o \\
o \\
+ \\
a \\
0\end{array}$ & $\begin{array}{l}\text { Cardiac failure } \\
\text { Collapse of lungs } \\
\text { Pneumonia } \\
\text { Septicaemia } \\
\text { Meningitis }\end{array}$ \\
\hline $\begin{array}{r}119 / 67 \\
135 / 67 \\
1704 / 67 \\
160 / 67 \\
2278 / 67\end{array}$ & $\begin{array}{l}\text { I year } 6 \text { months } \\
\text { I year } 5 \text { months } \\
\text { I year } 9 \text { months } \\
2 \text { years } \\
4 \text { years }\end{array}$ & $\begin{array}{l}q \\
0 \\
0 \\
0 \\
q \\
+ \\
0\end{array}$ & $\begin{array}{l}\text { Kwashiorkor } \\
\text { Kwashiorkor } \\
\text { Kwashiorkor } \\
\text { Kwashiorkor } \\
\text { Kwashiorkor }\end{array}$ \\
\hline $\begin{array}{r}144 / 67 \\
1812 / 67 \\
1969 / 67\end{array}$ & $\begin{array}{ll} & 5 \text { months } \\
\text { I year } & \text { I month } \\
\text { I year } & \text { I month }\end{array}$ & $\begin{array}{l}\hat{\sigma} \\
\partial \\
\partial\end{array}$ & $\begin{array}{l}\text { Marasmic kwashiorkor } \\
\text { Marasmic kwashiorkor } \\
\text { Marasmic kwashiorkor }\end{array}$ \\
\hline $\begin{array}{r}1620 / 67 \\
105 / 67 \\
1811 / 67 \\
1857 / 67 \\
158 / 67 \\
161 / 67\end{array}$ & $\begin{array}{l}8 \text { months } \\
\text { I year } 6 \text { months } \\
2 \text { years } \\
\text { I year } 4 \text { months } \\
\text { I0 months } \\
3 \text { years }\end{array}$ & $\begin{array}{l}0 \\
0 \\
0 \\
0 \\
0 \\
0 \\
0 \\
0\end{array}$ & $\begin{array}{l}\text { Marasmus } \\
\text { Marasmus and gastroenteritis } \\
\text { Marasmus } \\
\text { Marasmus and gastroenteritis } \\
\text { Marasmus and rickets } \\
\text { Marasmus and rickets }\end{array}$ \\
\hline
\end{tabular}

\section{Preparation of samples and determination of $\mathrm{Zn}, \mathrm{Cu}$ and $\mathrm{Mn}$}

Throughout the analytical work great care was taken to avoid contamination with metal substances. Borosilicate glassware cleaned in chromic acid and washed with glass-distilled water was used throughout. The liver obtained at post-mortem was washed externally with glass-distilled water and drained on a clean dish, and then a small piece was removed for the determination of the trace metals. This was transferred to a Potter-Elvehjem glass homogenizer and tissue homogenate was prepared from it with the aid of a small volume of glass-distilled water. The method of preparation of the other tissues was similar to the method used for liver. The only modification was that the homogenization step was omitted in heart, muscle and skin samples. The brain was frozen at $-4^{\circ}$ before dissection, transferred to a Pyrex glass dish and its outer surface washed with metal-free water. The excess water was removed by lightly blotting with clean paper tissues, and small pieces of cortex were dissected out with clean stainless-steel instruments. The brain was then sectioned and small 
portions of the deeper structures to be examined were removed with a stainless-steel knife with a thin blade.

The organic material was destroyed and the samples were oxidized by a modification of the nitric-perchloric-sulphuric acid method of Eden \& Green (1940). All reagents used were of AR or lead-free grade. Batches of each of the acids used in the destruction of the organic material were analysed for the presence of $\mathrm{Cu}, \mathrm{Zn}$ and $\mathrm{Mn}$ and those with the lowest concentrations of these metals were selected for analytical use. The $\mathrm{Zn}, \mathrm{Cu}$ and $\mathrm{Mn}$ content of each sample was determined by means of a Perkin Elmer 303 atomic absorption spectrophotometer. Reagent blanks were carried out with each set of estimations. Samples of the original tissue homogenate were dried to constant weight at $110^{\circ}$ for determination of dry-matter content.

\section{RESULTS}

The mean concentrations of $\mathrm{Zn}, \mathrm{Cu}$ and $\mathrm{Mn}$ in the various tissues of the four groups of children investigated are presented in Tables 2 and 3 . In the PCM groups there was some decrease of $\mathrm{Zn}, \mathrm{Cu}$ and $\mathrm{Mn}$ concentrations in most tissues except skin, brain stem and pons in which the concentrations were higher than in the control group.

\section{Zinc}

The only tissue in which the concentration of $\mathrm{Zn}$ was statistically significantly reduced compared with the control group was the liver of children with kwashiorkor $(P<0.00 \mathrm{I})$. With regard to brain tissues, the mean $\mathrm{Zn}$ concentrations in the cortical grey matter of the various groups were significantly higher than the mean $\mathrm{Zn}$ concentrations in the subcortical white matter $(P<0.001)$. There was no significant difference in $\mathrm{Zn}$ concentration between brain tissues of control subjects and PCM groups.

\section{Copper}

The mean $\mathrm{Cu}$ concentrations in liver and muscle were significantly lower in the children with kwashiorkor than in the control group $(P<0.001$ and $P<0.05$, respectively). The highest $\mathrm{Cu}$ concentrations in the brain were found in the cortical grey matter and basal ganglia. As with $\mathrm{Zn}$, the mean $\mathrm{Cu}$ concentration in cortical grey matter of all subjects studied was significantly higher than the means of the corresponding concentrations in subcortical white matter $(P<0.01)$. There was no significant difference in $\mathrm{Cu}$ concentration between brain tissue of control subjects and PCM groups.

\section{Manganese}

The mean Mn concentration in the liver was significantly lower in the children with kwashiorkor than in the control group $(P<0.05)$. The mean $M n$ concentration in heart muscle of all PCM children was significantly lower than the mean value for the control group $(P<0.05)$. There was no significant difference in Mn concentration in brain tissues between control subjects and the PCM groups. 


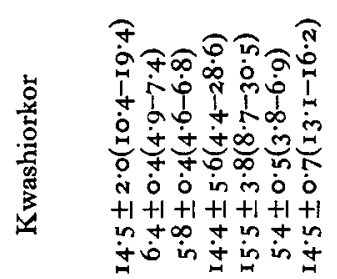

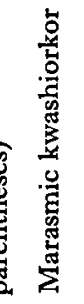

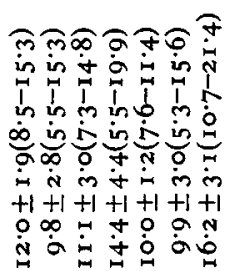

สิติว

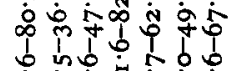

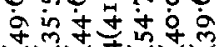

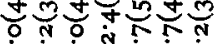
$\dot{0} \dot{0} \stackrel{\text { in }}{\text { in }} \dot{0}$ $+1+1+1+1+1+1$

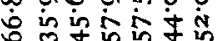

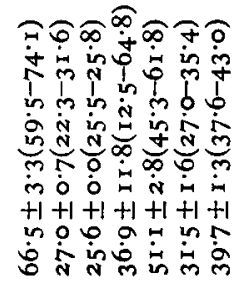

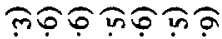

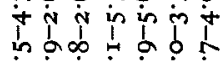

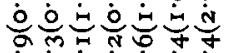
$\dot{0} \dot{0} \dot{0}$ i $\dot{0} \dot{0} \dot{0}$ $+1+1+1+1+1+1+1$ an $n$ îi

ดิศกิรลิก iि is in

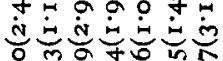
- $\dot{0} \dot{0} \dot{0} \dot{0} \dot{0} \dot{0}$ $+1+1+1+1+1+1+1$

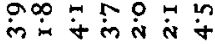

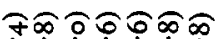

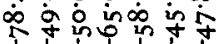
b t b to bo d 安实运 in

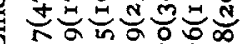

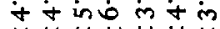
$+1+1+1+1+1+1+1$ काmm no

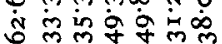

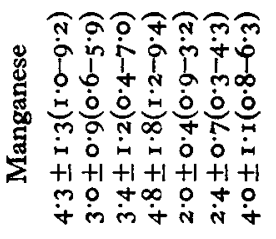

$+1+1+1+1+1+1+1$ ० ल०खण

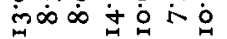

วิํํำ施

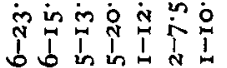

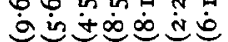
o숯

$+1+1+1+1+1+1+1$

- m un $N \infty$ no $\dot{0} \dot{\infty} \dot{\infty}$ in

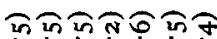

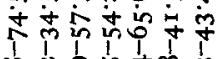
$\infty$ c 它 พ in $\dot{m}$ in $\dot{0} \dot{i}$ i $+1+1+1+1+1+1+1$ 今。

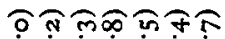
o in o in in i in

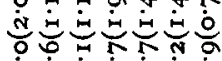
í $\dot{0} \dot{0} \dot{0} \dot{0} \dot{0} \dot{0}$ $+1+1+1+1+1+1+1$

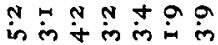
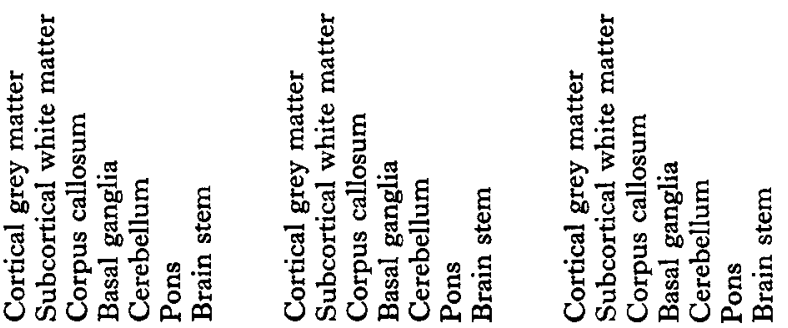
Vol. 26

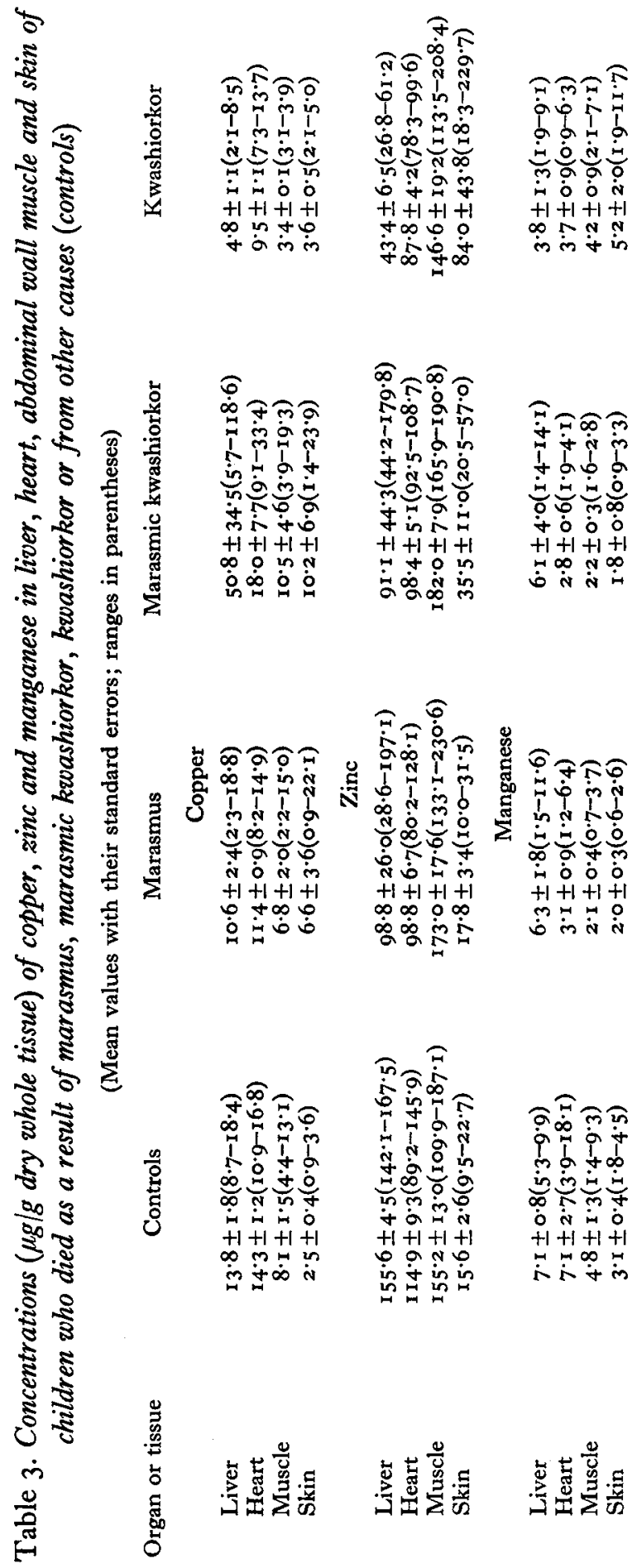




\section{DISCUSSION}

A general tissue deficiency of $\mathrm{Zn}, \mathrm{Cu}$ and $\mathrm{Mn}$ in subjects with protein-calorie malnutrition has not been unequivocally demonstrated in this study. In kwashiorkor we have confirmed our previous finding of a significant reduction of $\mathrm{Zn}$ and $\mathrm{Cu}$ in the liver (Warren et al. 1969), and demonstrated a lowering of the concentration of $\mathrm{Cu}$ in muscle taken from the abdominal wall and of $\mathrm{Mn}$ in heart muscle. We were unable to find any reports in the literature on tissue analysis of this kind in subjects with protein-calorie malnutrition, but the concentrations in our control subjects compare fairly well with normal values reported earlier (Warren, Earl \& Thompson, I960; Harding-Barlow, r96r). Small differences between normal trace-element concentrations in tissues reported by different workers are to be expected owing to age differences (Lea \& Walker, I964) and the variety of analytical methods. It is to be expected that the trace-element pattern in organs with a rapid protein turnover will be the most affected in states of protein deficiency. It is of interest that we found this to be so in the liver and not surprising that we found no significant differences in $\mathrm{Zn}, \mathrm{Cu}$ and $\mathrm{Mn}$ concentrations between brain tissues of control subjects and those with protein-calorie malnutrition.

It was of interest to find that the $\mathrm{Zn}$ concentration in the skin was not significantly lower in the children with protein-calorie malnutrition than in control subjects. In a previous communication (Hansen \& Lehmann, 1969), Zn concentration in the serum was reported to be reduced in children who had ulcerative skin lesions but this was not related to severity of the malnutrition or to rapidity of healing. The repeated therapeutic value of $\mathrm{Zn}$ in the healing of wounds and ulcers (Pories, Henzel, Rob \& Strain, 1967) may thus be a specific effect connected with the formed elements of the blood in which $\mathrm{Zn}$ becomes concentrated rather than an effect on tissue content per se (Husain, 1969).

We are grateful to our colleagues, Dr A. S. Truswell, Dr K. Schütte and Professor L. S. Smith for valuable advice and assistance. We also thank Professor J. F. Brock for providing facilities in the Council for Scientific and Industrial Research, Clinical Nutrition Research Unit, to the United States Public Health Service for grant No. A.M.O. 3995, and the South African Atomic Energy Board for financial support.

\section{REFERENCES}

Eden, A. \& Green, H. H. (1940). Biochem. F. 34, 1202.

Hansen, J. D. L. \& Lehmann, B. H. (г969). S. Afr. med. Y. 43, 1248.

Harding-Barlow, I. (I96I). Studies on the trace element content of human tissue. PhD Thesis, University of Cape Town.

Husain, S. L. (1969). Lancet i, 1069.

Jelliffe, D. B. (1966). The Assessment of the Nutritional Status of a Community. Geneva: WHO.

Lea, M. A. \& Walker, D. G. (1964). Archs envir. Hlth r7, 88I.

Pories, W. J., Henzel, J. H., Rob, C. G. \& Strain, W. H. (1967). Lancet i, I 21.

Warren, P. J., Earl, C. J. \& Thompson, R. H. S. (1960). Brain 83, 709.

Warren, P. J., Hansen, J. D. L. \& Lehmann, B. H. (1969). Proc. Nutr. Soc. 28, 6 A.

\section{Printed in Great Britain}

